Leadership as sustainability: context and primary school principals in Jamaica

$$
\text { Paul Miller*, }
$$

School of Education and Professional Development,

University of Huddersfield, UK

P.Miller@hud.ac.uk

Veronica Gaynor, Iris Gelly Primary School, Jamaica

gaynor_v@yahoo.com

Colington Powell, Friendship Primary School, Jamaica

collingtonpowell@yahoo.com

Shernette Powell, Point Hill Primary \& Junior High School, Jamaica

ljsherjamayne@yahoo.com

Eugenie Simpson, Sandy Bay Primary School, Jamaica

izestyby@yahoo.com 
Leadership as sustainability

\title{
Leadership as sustainability: Context and primary school principals in Jamaica
}

\begin{abstract}
School leadership is as challenging as it is rewarding. And, in a fast paced educational policy environment, school leaders sometimes are having to play catch up with the latest government mandate. This challenge is exacerbated in environments where economic and social problems, and lack of parental engagement in education are a daily occurrence and a significant risk to the effectiveness of schools. Whilst we recognise the notion of sustainable school leadership is continuing its evolution, we also acknowledge it is not a single act, and nor is it enacted by a single individual. Reporting findings from a qualitative study of primary school leaders in Jamaica, we argue that sustainable school leadership is not a new form of leadership, but rather a type of leadership that combines multiple practices to produce long-term impacts on members of a school community that are 'now' and 'futures' oriented.
\end{abstract}

Key words: Sustainable, leadership, school leaders, primary schools, Jamaica

\section{Introduction}

School leadership is a complex and unique opportunity to serve and influence the lives of individuals and the direction of a national education system. It is a fundamental ingredient in school success and a foundation stone in national economic transformation agendas. Without leadership that is 'now' and 'futures' orientated, schools may not be able to deliver national goals for education. Globally, school leadership is recognised as a vital element in transforming the lives of individuals and improving the prospects of societies. This important relationship is guided by two important and interrelated issues. That is, school leadership is both 'means' and 'ends' oriented. Thus, in its simplest form, school leadership has a developmental role to play in capacity-development among teachers, and an outcome-based role among students who must be provided with useful tools for life now and in the future. School leadership is, thus, not only 
Leadership as sustainability

about achieving short-term objectives, although these are essential, but also about achieving outcomes and impacts that are associated with long-term objectives.

School leaders operate in dynamic and spontaneous environments, and at any given point, their work and their schools must face up to the influence of a range of political, cultural, social, economic, legal, technological and personal factors (Miller, 2016). Although the range of factors are not fixed and may change daily, monthly, yearly, with a change in government and in line with global events, the expectations and demands placed on school leaders for improvements in quality and outcomes are constant. As might be expected, due to the embedding of performativity cultures in schools, and as governments demand much more from schooling and schools, it is expected these demands will only intensify. Noting that the embedding of performativity is an expectation also associated with other professions, , Scott (2013) noted:

Schools are not alone in having this expectation placed upon them as it now falls to all institutions: hospitals, banks, car dealerships, estate agents, broadcasters, supermarkets, hedge funds, hair dressers, etc., to, not only do something about sustainability, but also learn about what they do through doing this. (p.3)

This important observation illustrates that leaders need to implement sustainable leadership practices. However, for these practices to matter and to have an impact, leaders need to possess an understanding of what is meant by sustainable leadership, as well as being able to reflect upon and assess the impact of their practices. In the context of school leadership, the combination of political, cultural, social, economic, legal, technological and personal factors and demands identified above, working together and/or against each other, enables us to understand how a school leader constructs and does sustainable leadership in their context. 
Leadership as sustainability

By necessity, school leaders have to "do education differently" (Miller, 2012, p.9). This is not only as a response to the changing needs of student cohorts, but also as a direct response to constantly changing national educational policy environments, reduced spending on education, as well as a response to social events such as mass migration. These factors are not likely to go away any time soon, and together, they are having an impact on the school leader and what it means to do sustainable leadership, globally and in Jamaica. As a result, and through a counter-discourse of resistance, school leaders in Jamaican primary schools are re-imagining their work through innovative practices and in ways that mitigate the impact of reduced funding, promotes partnership working, promotes personal and capacity development among staff and students, promotes curriculum diversity and practices shared leadership.

\section{The context of leadership}

As earlier noted, schools are operating in times of rapid environmental change where, "There is a growing concern that the role of school principal designed for the industrial age has not changed enough to deal with the complex challenges schools are facing in the 21 st century" (Pont el al, 2008, p.16). The speed and effects of national policy and other environmental changes, are compounded by challenges associated with teacher shortage and quality, the quality leadership and a relatively narrow pool of teachers applying for the principalship, which together, have huge potential to impact if not undermine the notion and practice of sustainable school leadership. These are real challenges for any national education system, but in particular a developing country such as Jamaica, which, for one reason or another, may lack the technical, financial and human capacity to respond to or resolve these issues adequately and in a timely manner.

Thus, the volatility of national educational environments is pushing school leaders to stretch their leadership in ways that are more resilient, more flexible, and more adaptable by engaging leadership as both an art and a science, and by developing and implement, policies 
Leadership as sustainability

and systems that are 'now' and 'futures' oriented. Acker-Hocevar et al (2015) note that, "School leadership is not simply putting prescribed solutions into action, but a constant encounter with quandaries that demand thinking and problem solving, responding, and adjusting to the situations at hand" (p.5). Put differently, remaining focused on a school's longer term goals, whilst being sufficiently creative and flexible in their approach to leadership is important to our understanding of how school leaders conceptualise and enact sustainable leadership for two clear reasons. First, as the demands of a national educational environment are more firmly embedded in the everyday practice of schooling, school leadership “... requires an approach that is neither top down nor bottom up but one that is encompassing, synergistic, innovative and practical" (Miller 2012, p.9). The importance of flexible and integrative leadership was also highlighted by Ulrick and Bowers (2013) who argue, "Principal perception and, in turn, principal behavior determine the extent to which school leaders influence organizational change for student improvement" and "Principals increase the extent of their influence over school improvement by sharing leadership with teachers" (p. 98). Second, school leaders are making better use of the skills, talents and capacities of others in order to develop and spread capacity through-out their organisations (Harris and Spillane, 2008) as well as to ameliorate potential ill-effects associated with lack of planning for leadership succession (Bush, 2011).

\section{School leadership research and practice in Jamaica}

Although much has been written about education in Jamaica, sustained research into the theory and practice of school leadership in Jamaica is an emerging field with very little published work in this area before 2010. And from 2010 to date, only two major studies have been conducted on the practice of school leadership on the island. From his national study of High Performing Principals in Jamaica, Hutton (2011) identified nine factors that made a significant difference in the overall performance and effectiveness of a school and students' 
Leadership as sustainability

outcomes. These were: having a philosophy of self and school; acknowledgement of the importance of personal characteristics, abilities and qualities; demonstrable situational and transformational leadership behaviours; a supportive platform for student growth and development; focus on students' academic performance and achievement; emphasis on strong staff involvement and support; acknowledgement of the psychological benefits of a wellmanaged school plant; broad-based community relationship; and a cordial, although sometimes fractious relationship with the Ministry of Education (MoE). Hutton's study highlights a number of important characteristics which are crucial to our understanding of sustainable leadership practices among Jamaican school leaders.

In his national study of teacher aspiration and progression toward the principalship, Miller (2013a) found promotion/ progression were based primarily around four 'marks', namely: political affiliation; religious affiliation; social connections; and jockeying or institutional interference. Miller's" study highlights two important things in relation to the issue of sustainability and school leadership. That is, progression based on "marks" of affiliation and not merit was leading to demoralisation among those aspiring to become school principals, corrupt progression/ promotion practices places the quality and effectiveness of leadership at risk.

In addition to these studies, there have been several publications which have added to our understanding of school leadership as a field of practice and theory in Jamaica. In, School Leadership in the Caribbean, (Miller, 2013b) theorised that the large numbers of women teachers and school leaders in Jamaica (and elsewhere in the Caribbean) is a feature and an outcome of historical, socio-cultural beliefs and religious teachings (e.g.: in biblical teachings) that construct women as nurturers, possessing responsibility for the social, emotional and educational development of children. In Exploring School Leadership in England and the Caribbean (Miller, 2016) reported school leaders were struggling to keep pace with the speed, 
Leadership as sustainability

volume and content of educational policy directives, engaging more with technology in schooling, distributing leadership (although mostly as a response to work intensification) and were steeped in entrepreneurial leadership and income generating activities due to national economic conditions. In Leadership for Success: The Jamaican School Experience, Hutton and Johnson (2017) noted that successful school leaders shared leadership, worked closely with parents and school communities, addressed indiscipline amongst students and used multiple approaches to motivate and develop staff.

\section{Education in Jamaica}

In Jamaica, there are just under 1,200 state-funded schools: 206 state-funded secondary schools and technical high schools, and 973 pre-primary, primary, all-age and junior high schools. In 2016, the education system catered to about 850,000 students in public institutions at the early childhood, primary and secondary levels. There are approximately 25,000 teachers in the state-funded sector, including just under 1, 200 principals who have an important role to play in helping the country to attain "developed" country status by the year 2030 , an ambition which, if realised, could result in significant improvements for social and economic facets of the populace as a whole (Ministry of Education, 2016).

Over the last decade, Jamaica's education system has introduced several reforms. For example, recommendations in the Report of the Task Force on Educational Reform (2005) led to the establishment of a National College for Educational Leadership, a National Education Inspectorate, a National Council on Education, the Jamaica Teaching Council and the Jamaica Tertiary Education Commission. The Education System Transformation Programme was followed, in 2010, by the Education Sector Plan of 'Vision 2030: National Development Plan Jamaica', an ambitious multifaceted programme of activities and initiatives aimed at charting Jamaica's path to 'developed' country status by the year 2030. Education in Jamaica is 
Leadership as sustainability

administered primarily by the Ministry of Education (MoE), through its head office and six regional offices. Formal education is provided mainly by the government, solely or in partnership with churches and trusts. Formal education also is provided by private schools. As stipulated in the 1980 Education Act, the education system consists of four levels: early childhood, primary, secondary and tertiary. There is a cost-sharing mechanism in place in Jamaica to fund education which is not free to students.

\section{Sustainability}

The precise meaning of the concept of sustainability is still evolving. It has been defined in the report of the United Nation's (1987) Brundtland Commission as ensuring that development, “....meets the needs of the present without compromising the ability of future generations to meet their own needs" (p. 6). This definition suggests human actions, in particular those of leaders, should seek not only to achieve short-term, but also long-term outcomes in ways that benefit the many and not only the few.

Sustainability encompasses three interlocking elements: environmental (planet); social (people); and economic (economy). According to Elkingon (1997), a society depends on its national economy to prosper and a national economy depends on a successful global ecosystem in order to flourish. This important interlocking relationship is re-affirmed by Scott (2013) as central to individual and societal futures. He argued:

Schools, however, along with colleges and universities, can be under no such illusions, as they have the extra imperative of remembering that their raison d'être is to help young people learn about such matters (along with a host of other things). For these institutions, it seems clear that, if choices have to be made between helping young people learn and, say, saving carbon, then it is the former that needs to take priority. (p.3) 
Leadership as sustainability

As mentioned earlier, globally, a major focus of current educational policies at national level is economic development and prosperity for now and the future. This major focus has been translated into curricular content, performance objectives, improvement targets and accountability mechanisms and systems. Based on the definitions of sustainability, we propose that sustainable leadership focuses, simultaneously, on improvements in the environmental, economic and social spheres - such as those identified and discussed in this paper.

\section{Sustainable leadership}

Like sustainability, a precise understanding and definition of sustainable leadership is also an evolving issue, leading to a range of descriptors and characteristics being offered as clue for what it is or should be. Hargreaves and Fink (2003) proposed:

Sustainable leadership matters, spreads and lasts. It is a shared responsibility, that does not unduly deplete human or financial resources, and that cares for and avoids exerting negative damage on the surrounding educational and community environment. Sustainable leadership has an activist engagement with the forces that affect it, and builds an educational environment of organizational diversity that promotes cross-fertilization of good ideas and successful practices in communities of shared learning and development. (p.3)

In a later paper, Hargreaves and Fink (2004) expanded their characterisation of sustainable leadership to provide seven principles. They suggest:

- Sustainable Leadership Matters: provides holistic and meaningful learning that engages students intellectually, socially and emotionally and that equip them for life beyond test scores and examinations (Glickman, 2002; Stoll, Fink, \& Earl, 2002).

- Sustainable Leadership Lasts: increasing the likelihood of stable leadership by planning and preparing for succession. 
- Sustainable Leadership Spreads: shares and distributes leadership as a means of talent management and multiple level whole school capacity development (Spillane et al., 2001). Although uniquely personal, school leadership is a collective endeavor (Miller, 2018).

- Sustainable Leadership is Socially Just: ensures that leadership decisions and actions consider their impact on the greatest number of students, as well as on other schools, in particular, neighboring schools (Hargreaves \& Fink, 2004). As the actions and outcomes of schools affect each other in webs of mutual influence (Baker \& Foote, 2006), school leaders (should) show concern for schools and students in other schools located within a community and/or nationally.

- Sustainable Leadership is Resourceful: attracts, recruits, and retains the best talent. Furthermore, by accessing multiple networks (professional, business, etc), leaders can secure significant benefits of time, skills and resources for their schools since no school can go it alone (Miller, 2018).

- Sustainable Leadership Promotes Diversity: creates an environment that recognizes and celebrates multiple best practices (Capra, 1997). Standardisation is an enemy of sustainability and sustainable leadership does not impose standardised templates on everyone (Hargreaves \& Fink, 2004).

- Sustainable Leadership is Activist: engaging individuals and the community in patterns of mutual influence, and by creating change through innovative ways of working and active leadership (Oakes, Quartz \& Lipton., 2000).

Although not offering a definition, Fullan (2005) proposed eight elements of sustainable leadership which are broadly consistent with the seven principles set out by Hargreaves and Fink (2003). Despite these similarities, however, we believe it is important to outline the elements identified by Fullan, since there is a paucity of academic and empirical research in 
Leadership as sustainability

this area, and since the elements identified by Fullan are sufficiently different they will enable our understanding of the evolution of the concept of sustainable leadership and of the concept itself. These eight elements are:

- Public service with moral purpose: raising the bar and closing the gap in student learning; changing the social environment;

- Commitment to changing context at all levels: supporting individuals and systems through the creation of a nurturing and supportive environment;

- Lateral capacity building through networks: learning from and with peers; multiple level collaboration to foster, develop and disseminate innovative practices;

- Intelligent accountability and vertical relationships: working closely with established state agencies to support and improve internal activities and quality judgments;

- Deep learning: creating collaborative learning cultures that move away from dysfunctional and non-relationships towards collective problem-solving;

- Dual commitment to short-term and long-term results: not allowing for complacency by setting goals that are realistic for an organisation given its capacity and resources;

- Cyclical energising: pursue opportunities and strategies that are likely to result in improvements and increase the likelihood of continued improvement against targets/ goals; and

- The long lever of leadership: having in place leaders at all levels, who are trained to think and act in ways that influence the good of a system and not just a single school. (pp. 14-27)

\section{Competencies of sustainable leaders}

Turning to the "Business" literature, we draw on Strandberg (2015), who identifies five behaviours and competencies associated with sustainable leaders. These are: 
Leadership as sustainability

- Systems thinking: they are connected, holistic thinkers that understand the context behind a problem and its relationship to broader trends. They also understand the layers and complexities of relationships in the system within their business is located.

- External collaboration: they are willing to work with other organisations as is necessary. Collaboration helps organisations build social capital, explore new market opportunities and shape the contexts in which they operate.

- Social innovation: they see challenges as growth opportunities, and they simplify and re-design processes in ways that produce maximum output and greatest value.

- Sustainability literacy: they are aware of emerging environmental and social trends and how these could impact their organisations.

- Active values: they demonstrate awareness of self and the system as a whole, and being able to develop and pursue higher purpose within self, teams and their organisations to nurture and support personal and organisational transformation (pp. 4-13).

We draw on Hargreaves and Fink (2004), Fullan (2005) and Strandberg (2015) notions of "meaningful/ deep learning”, "growing leadership/ capacity development" and "resourcefulness", as an analytical framework to be used in the discussion section. Furthermore, drawing on Hargreaves and Fink (2003; 2004); Fullan (2005) and Strandberg (2015), and in the absence of a sufficiently developed body of academic/ empirical literature and related definition of sustainable leadership, we herein propose that, "Sustainable leadership is not one single thing. Rather, it is a combination of a series of planned actions aimed at developing and/or multiplying the likely social, economic and environmental benefits from resources available today for use in the future". 


\section{The study}

This qualitative study of sustainable school leadership practice among Jamaican primary school leaders was undertaken during the period April 2016 - February 2017. The study was commissioned by the Institute for Educational Administration \& LeadershipJamaica (IEAL-J), for a PrinMeet Plenary session at the IEAL-J's 2017 International Conference on Educational Leadership \& Management, held in Jamaica in March 2017 under the theme, "Educational Leadership for Sustainability: Current Realities, Future Possibilities". All four school leaders involved in the study are IEAL-J members. The primary purpose of the study was to identify how these primary school leaders practice sustainable school leadership. The main interview and subsidiary questions were:

- What challenges are present within your work/school context, to you being able to demonstrate sustainable leadership?

- What opportunities does your work/school context provide you to demonstrate sustainable leadership? How do you harness and expand these opportunities?

- Given the challenges of your work/school context, how do you lead in ways that make meaningful change for students? What initiatives and strategies do you employ to secure short, medium, long term objectives/ change?

In-depth interviews were conducted with each school leader in their workplace - each lasting between 60- 75 minutes.

\section{Participants and their schools}

Four primary school principals located in three parishes in Jamaica were involved in this study. All participants work in public schools or schools run/funded by the national education ministry. There were three females and one male. Hereafter, we refer to principals as P1, P2, P3 and P4. P1 leads a school in a semi-urban community in western Jamaica, located 
Leadership as sustainability

in close proximity to several hotels and tourist attractions. Although the area within which the school is located is reasonably well-off, the school itself is under-resourced, a large number of the students are poor. At the time of this study, P1 had been in teaching profession for 23 years and a principal for 3 years. P2 leads a school in an urban working class community in central Jamaica. A number of small shops and small businesses are located close to the school, and many parents are vendors at the gate. Despite it's location and community context, the school is reasonably well resourced due to donations from large businesses - associated its year-onyear success in national competitions. At the time of this study, $\mathrm{P} 2 \mathrm{had}$ been in the teaching profession for 20 years and a principal for 9 years. P3 leads a school in a rural/remote working class community in central Jamaica. There are no large or medium sized businesses located in the community and small-scale farming is the main income source for parents. At the time of this study, $\mathrm{P} 3$ had been in the teaching profession for 13 years and a principal for 2 years. $\mathrm{P} 4$ leads a school in a working class community in inner-city Kingston Jamaica. A number of small shops and small businesses are located within the school community, and many parents own or work in these small shops or conduct vending at the gate. The community itself is prone to uprising between rival political gangs, which sometimes lead to school closure. Despite it's location and community context, the school is reasonably well resourced due to donations from large businesses - associated its year-on-year success in national competitions. At the time of this study, P4 had been in the teaching profession for 25 years and a principal for 9 years.

\section{Analytical approach}

Qualitative interview data was collected which were analysed using narrative poststructuralism. By choosing this approach, we wanted to focus on the discourse and narratives of school leaders related to social institutions (e.g.: schools) and cultural products (e.g.: a national education system). According to Foucault (1981), "Discourse transmits and produces power; it reinforces it, but also undermines and exposes it, renders it fragile and makes it 
Leadership as sustainability

possible to thwart it" (p.101). Discourse therefore is a useful tool for understanding practice since narratives constructed by actors are often subsumed into the actions that comprise their practice. Ethnographic methods and procedures (such as key informant interviewing) were also used to generate critical insights from school leaders in relation to their practice in their institutional settings, which allowed the researcher access to events, discourses and tactics used by different school leaders in different school contexts which may not have been [adequately] captured by quantitative methods. Incorporating ethnographic methods within the analysis of data was therefore a methodological and a political act for giving voice to school leaders, especially primary school leaders in small, rural/ remote schools, as well as for zeroing in on how school leaders emancipate their leadership despite challenges within and outside the school context. The interview excerpts included in this paper are therefore to illustrate and enable our understanding and analysis of discourses, actions and 'events' in these spaces.

\section{Findings}

\section{School context and characteristics}

The school leaders in this study led schools with very similar and experiences although the schools were relatively different in terms of size, location, and staffing, etc. Some key similarities and differences are set out in Table 1.

\section{TABLE 1: HERE}

We wish to point out that, in Jamaica, the term working class is broadly applied to different sub-categories to include: those who have low incomes, those who are just about managing, and those with no income. As provided by principals:

Parents are from poor socio-economic backgrounds. A few work at the nearby sugar plantation, others do subsistence farming; but the majority do not work or do odd jobs (P3, female, rural/remote school). 
Leadership as sustainability

Parents are largely from lower economic means, with nearly $50 \%$ being unemployed.

Those who work are vendors, shopkeepers, bartenders, hairdressers, construction workers. Some are even involved in illicit activities (P2, male, urban school).

\section{Challenges of context}

School leaders identified a number of challenges associated with each school. Although some challenges were arguably more acute, depending on where the school is located, a number of common challenges were identified.

\section{Availability of piped water}

This was a major social challenge for some school leaders. Although some had piped water connected to the mainline, others relied on rain-fall or water being trucked in. Not only was this a health and safety issue, it was also an operational concern.

Although the school is connected to the public main, water is restricted for as much as 5 months of the school year. This affects the entire community. Unless water is trucked to us, activities at school have to be curtailed (P4, female, inner-city school).

Water comes to the school only via water truck or rain fall, hence, we use a water catchment system. As principal, I acquired two additional water tanks and I am in the process of reconstructing proper guttering system which will make it easier for the tanks to be filled when it rains (P3, female, rural/ remote school).

\section{Security personnel}

This was another social major issue for school leaders. Some schools were without security personal and those with security personnel found it difficult to convince them to work at nights. 
Leadership as sustainability

The Ministry of Education has three full time and three part time watchmen employed to the institution. Despite being placed on night duties, watchmen cite fear as reasons they refuse to do night duties. (P4, female, inner-city school)

We do not have security guards at school, but I think this would help. We have perimeter fencing, but sometimes young men from neighbouring communities simply jump the fence and walk through the school grounds as if it's a short cut. So I believe having security guards on site would help (P1, female, semi-urban school).

\section{Availability of material and resources}

All school leaders suggested their schools are under-resourced- although not to the same degree.P3, located in a rural/ remote community appear to experience resource constraints more severely.

Materials and supplies are mainly acquired through partnerships outside of the education ministry. The principal ensures that a lot of networking is done with other school principals and non-governmental organisations in order to make ends meet. There is a strain on the administration as some very important equipment is not at the school at this time. There is no printer, no photocopier and no telephone. The principal uses her personal telephone to make calls on behalf of the school without any refund on telephone charges. Where there is a need to print examination papers, I have to ask my husband, another principal to assist. Teachers also bring their laptops to school as we only have one school laptop, which is used by the principal's secretary. (P3, female, rural/ remote school)

It is not uncommon for teachers to use their own money to purchase material and resources for teaching. Not only do we not have the funds, and the ministry grant is usually late, we cannot ask parents for any financial assistance as they simply do not 
Leadership as sustainability

have it. There are several things we simply do without or we make do with what we have. (P4, female, inner-city school)

\section{Parental engagement/ involvement}

As used by school leaders in this study, parental engagement includes such activities as assisting with homework, providing learning material and resources to students, attending school/ tutor consultation, etc. On the other hand, parental involvement includes taking part in sports day, fundraising events, and projects such as painting of classrooms or beautification of school grounds. This distinction is useful in enabling our understanding of how parents interacted with schools.

Parental engagement (in education) is below average but school activities such as sports and fundraising activities are generally well supported. (P2, male, urban school)

Parental engagement is a priority item in the School Improvement Plan. It is a tough community to pastor; it is a tough community to educate. Not many parents take an active role in the schooling of their children. Of the 505 students, average attendance at Parent Teachers' Association meetings (PTA) is 60. We find that at grades one and six parents are generally supportive, and this coincides with when students are starting out and when they are about to take the GSAT exams. (P1, female, semi-urban school)

Drawing on the talents, skills and good will of parents was important to school leaders' being able to deliver many of the improvements, in particular, improvements to the physical plant. Furthermore, it was also recognised that parents were an important element, with crucial roles to play, in making school leadership sustainable.

An activity like 'fun day' at school gets massive support... harvest, fundraisers, prize giving. However, parents have to be hassled to buy textbooks and other resources that the children need from time to time...the school is trying to cultivate a different mindset 
Leadership as sustainability

in the parents... They do not always turn out for meetings or other school events (except for graduation), although in this past few months, when called for individual consultation they are usually cooperative. (P1, female, semi-urban school)

Nevertheless, the tension between engagement (in education) and involvement (in activities) was as helpful as it was problematic for school principals.

Getting parents to engage with us as a school and with the education of their children is an area of development for us. We do get support from parents however in terms of everyday school activities such as painting classrooms, sports day, etc. This is not good enough really, but I think the fact that they are involved provides myself and staff with a good opportunity to build on their involvement, and convert this into engagement with their children's actual education (P2, male, urban school)

\section{TABLE 2: HERE}

\section{Opportunities of context}

Despite the challenges associated with schooling in their school or community context, school leaders also provided insights and examples of opportunities within their context for them to demonstrate sustainable leadership.

\section{The provision of enrichment activities}

Despite not being gifted with adequate resources, wealthy and supportive parents, school leaders harnessed the resources available to them to provide students with the best experience possible.

No activity is considered too prestigious and elite for our school and as such our students are immersed in table tennis, chess and the National Schools' Challenge Quiz competition, etc. It must be pointed out that we have been doing extremely well in 
Leadership as sustainability

several of these areas, defeating several Preparatory and other "name brand" schools, which brings great joy and pride to the school community and our students and parents in particular. (P2, male, urban school)

Our school is situated on a huge amount of land. We often take students outside and teach them about landscaping, recycling, the wildlife and caring for the environment. (P1, female, semi-urban school)

\section{Personal development}

In addition to enrichment opportunities for students, school leaders consider their school context as important training grounds for building and harnessing their own leadership skills and abilities.

My school provides me a great opportunity to sharpen my leadership skills. It gives me the opportunity to help mould students for the secondary education system. It encourages me to be the best of me. It teaches me to be creative since I have to use unconventional methods to reach the goals of the school and those of the education ministry. It has strengthened my epistemologies. It has also enhanced my negotiating skills, mediation skills and leadership skills. (P3, female, rural/ remote school)

I am a much more resilient person for working in my school community and my school. I negotiate with "Area Dons" to get my staff and students in and out safely, and I beg money and resources from local businesses and bigger businesses in corporate Jamaica to help with several initiatives. So yes, I too am developing in many areas... (P4, female, inner-city school) 


\section{Capacity development among staff}

In addition to students and themselves being developed in the context of the schools, school leaders also showed emotional intelligence and responsibility towards the learning and development of all staff so they can better serve the students.

My school context provide opportunities for me to help staff to be more accountable and to develop their sense of professionalism. I also help them develop their leadership competencies. They are put in charge of different job roles and activities which help them. I also help them to be creative, and this is support by ongoing continuous professional development. Furthermore, as a school, we try to cater to the academic, physical, spiritual and cultural development of all students. They are taken on fieldtrips and are provided with different enrichment activities in order to expose them to different things and in order to develop their unique and God given skills and talents. (P3, female, rural/ remote school)

We do a range of professional development activities to support staff. The school has several demands, and given it's located in an area that many people may not want to readily volunteer to work, myself and the Board have to find opportunities to develop staff through additional responsibilities and by providing them with in-house seminars and workshops on different topics. This helps to support and motivate them. (P2, male, urban school)

\section{TABLE 3: HERE}


Leadership as sustainability

\section{Making leadership sustainable}

School leaders provided several examples and insights into how they 'do' sustainable leadership, despite contextual limitations.

\section{Leadership innovation}

School leaders acknowledge that for leadership to be successful and sustainable, school leaders have to be imaginative and innovative in their thinking and ways of being.

Being fully mindful of the social and other contexts, within which our school operates, the "brand" of leadership cannot be conventional in a number of ways. A large part of the thrust of the leadership of the school is to make the various members of the school community see the school as an "oasis in the desert". And notwithstanding its physical location, a largely depressed community, one gets the distinct feeling that parents, students, and community members expect a first rate school. This is evidenced by their high expectations in all aspects of our operations. As head teacher therefore, a big part of my role is to ensure that as many media are implemented for students to showcase and develop their talents. It should be noted that students are eager to learn new skills and often quickly master them. (P2, male, urban school)

In using the yard space outside to support learning, we are connecting with is in the textbook to the world at their fingertips. It's one thing to be under-resourced financially, but it's an advantage to have relatively fresh air and natural resources on your doorstep. (P1, female semi-urban school)

\section{Accountability and support}

Making it clear what is expected from middle leaders, teachers, parents and students is important in making leadership sustainable. Furthermore, by putting in place support plans 
Leadership as sustainability

alongside targets, and by implementing monitoring and accountability mechanisms, school leaders are showing how they demonstrate and harness sustainable leadership capacity.

The aim has always been to create an accountable culture and a value added culture not only to drive school progress, but to make it a sustainable one. Action are designed and strategies employed to hold teachers accountable for the performance of their students, students accountable for their learning, and parents accountable for the discipline and performance of their children.... Strong emphasis is placed on monitoring; middle managers are set clear goals... we have created a data-driven, evidenced based environment... keen attention is paid to evaluation as this informs planning at all levels... on-going building of capacity... system of rewards for staff motivation and student motivation...technology infusion in all aspects of school life. (P1, female, semiurban school)

At the centre of our Improvement Plan is sustainability. Granted, due to the demands placed on us by the ministry, we work in a very short term way. But, if you take our plans as a whole, you will see they have intentions beyond the everyday. ( $\mathrm{P} 4$, female, inner-city school)

\section{Partnership working/networking}

Partnership working and leverage capacity and resources from external networks and contacts was seen as a primary factor in making leadership sustainable, as well as in making interventions more likely to succeed and thus more beneficial.

To ensure we are in the best possible position to be able to adequately respond to the needs of students, as a school, we network with bigger schools and with other principals. I also form partnership with local political affiliates which provide financial support. I have also initiated a Past Students Association that has helped by providing much 
Leadership as sustainability

needed resources such as books, pencils, bags and shoes to help some of our poorer students. (P2, male, urban school)

No school can afford to survive on its own, and this is why I am grateful that the ministry has put schools into clusters. I work closely with other principals inside and outside my cluster, and with businesses and university lecturers to get the best possible help and support for my staff and students. (P3, female, rural/ remote school)

\section{Attributing sustainable school leadership}

Derived from the findings of this study, we summarise in Table 4, some key attributes we believe are associated with sustainable school leadership- evidenced in the practice of participants.

\section{TABLE 4: HERE}

\section{Discussion}

Two broad areas for discussion have emerged from the above findings: the relationship between school leadership and context and the relationship between leadership and sustainability. These are discussed in turn below.

\section{Leadership and context}

Although this is not the case for all schools on the island, many schools in Jamaica are poorly or under-resourced. Two principals in this study confirmed their schools are fairly wellresourced whereas the other two schools are fairly under-resourced. This, against a backdrop of two major issues. First, year on year reduction in government spend on education due to a steady decline in the government's ability to fund the public sector. Second, due to ongoing economic challenges induced by and associated with a 2012 loan deal with the International Monetary Fund (IMF) - an element of which is a freeze on public sector spending for five years. 
Economic conditions in Jamaica are compounded by the inability of several parents to contribute financially towards their children's education; neither in response to a reduction in government spending on education or as a parental duty. Furthermore, many schools are located in relatively poor communities where parents are primarily low waged, unemployable and unemployed individuals. Together, these factors presents a high degree of risk and a major hindrance to schools and school leaders being able to effectively and adequately contribute to the realisation of Vision 2030: National Development Plan Jamaica (PIOJ, 2010).

In addition to parents being unable to contribute financially to their children's education, evidence from this research suggests parents are also not in the strongest position to contribute in other ways also. That is, although parental involvement in practical aspects of schooling is significant and welcomed by school leaders, parental engagement with homework, learning and development, and broadly in terms of scaffolding the work of teachers and schools, is an area of particular concern and a relative threat to the sustainability of schools. The interconnected relationship between parental social class and school engagement should not be ignored; and neither is the fact that the relative absence of parents from school discourses places greater strain on teachers and principals in making the education they provide to students appropriate to their flourishing both now and for the future.

Context shapes leadership, and in a small country with an evolving (and sometimes conflictual agendas (Miller, 2016), focused primarily on national economic development, there is an apparent disconnect between the educational policy rhetoric and the ability of schools to achieve the mandates and benefits of policy agendas such as Vision 2030: National Development Plan Jamaica. This is not to say, educational policies are superfluous, rather, it is to highlight the fact that, without adequate funding from government, to back school leaders and schools, and to support parents when they are unable to meet their financial obligations to schools, the entire plan is at risk of being derailed. This apparent disconnect highlights the 
Leadership as sustainability

chaos that can occur to schools when educational change agendas and the realities of schooling are not in sync (Gunter, 2005). Furthermore, as Vision 2030: National Development Plan Jamaica, is a significant national policy, driving actions and aspiration among actors within and outside the nation's education sector, it would seem appropriate that its intended outcomes are connected with social, political, technological and economic, cultural factors, in ways that understand and appreciate events and life in local school communities, in particular, small school communities (Miller, 2015).

\section{Leadership and sustainability}

As provided earlier by Hargreaves and Fink (2004) sustainable leadership has seven principles. Furthermore, as proposed by Fullan (2005), sustainable leadership has eight elements. Additionally, Strandberg (2015) provides six competencies of sustainable leaders. Taken as a whole, these principles, elements and competencies provide a framework for what sustainable school leadership practices look like. We draw on Hargreaves and Fink (2004), Fullan (2005) and Strandberg (2015) to highlight and make a claim for several sustainable leadership practices among Jamaican primary school principals in this study. These are presented and discussed below.

Meaningful/ deep learning

School leaders are engaged in several activities to develop and bolster learning among students. From different enrichment activities for students to continuing professional development (CPD), and the monitoring of teaching, school leaders understood and enacted their role in trying to provide students holistic and meaningful learning (Hargreaves and Fink, 2004; Fullan, 2005) that engages them spiritually, intellectually, socially and emotionally and that equip them for life beyond test scores and examinations (Glickman, 2002; Stoll et al., 2002). There is evidence of this among all school leaders, who used the resources available in 
Leadership as sustainability

their school and community contexts to secure and promote a range of enrichment opportunities to provide students with "a qualitatively different learning experience” (Miller 2016, p. 106). For example, we see evidence of innovative thinking and teaching through the use of a school's outdoor space as an effective teaching tool and resource, in bringing learning to life, and in "making do with what we have" (P4). Thinking and acting outside their limitations, in the ways these school leaders have done, highlights practical and pedagogical commitment, thus confirming "...principal behavior determine the extent to which school leaders influence organizational change for student improvement” (Ulrick and Bowers, 2013).

“Growing leadership"/ capacity development

We see evidence of school leaders providing teachers with targeted continuing professional development activities and opportunities to develop capacity in their specialist subjects, and to improve general professionalism. This is particularly instructive since, there is broad consensus that teachers are the single most important school factor influencing student learning. Furthermore, quality teachers produce quality learners, which can only result in positive outcomes for the country practices align to support the realisation of Vision 2030.

We also see evidence of school leaders planning for and preparing for succession by actively distributing leadership through school, including to students, not only as a means of talent management and multiple level whole school capacity building (Spillane, Halverson, \& Drummond, 2001), but also as a mechanism for what we call "growing leadership". Although uniquely personal, school leadership is a collective endevaour (Miller, 2018), and school leaders suggested they were not merely into distributing or sharing leadership, but they were very much interested in growing and/or nurturing all teachers, but in particular those who aspire to formal leadership. This they felt was an important role they had, not least because their school context demanded they shared leadership meaningfully, but because sustainable 
Leadership as sustainability

leadership is concerned with and has priorities that extend an individual or the individual school leader. The important link between growing leadership and sustainability is signaled by Ulrick and Bowers (2013) who noted, "Principals increase the extent of their influence over school improvement by sharing leadership with teachers" (p. 98).

\section{Resourcefulness}

This was a particular area of strength among school leaders. In the case of P2 and P4, they lead schools in communities prone to gun and gang violence that sometimes disrupt teaching for extended periods. Similarly, P3 leads a school located in a rural/remote community. These school leaders however showed initiative, innovation and entrepreneurialism in being able to attract, recruit and retain quality teachers to schools located in communities that are hard to staff due to the issues related to their physical safety and in the case of P3, due to poor road conditions and lack of modern toilet and other facilities for students and staff. In promoting or showcasing their schools, school leaders were not only selling a vision but also a promise: a promise that they would, in partnership with teachers and others, work to bring about change and improvements to the lives of students and local communities.

Furthermore, by working closely with the education ministry, community actors and parents to leverage material, labour and financial resources, the school leaders were able to secure significant technical and financial benefits for their schools. Clarke \& Wildy (2016) argue that being an effective school leader, “...therefore, takes not only functional knowledge, understanding and contending with matters of compliance, but also confidence, determination and political sophistication" (p.47). Political sophistication, they argue, is being able to adapt and align external policy dictates to a school's capabilities and purpose. This argument is sustained in the overarching practice of school leaders in this study who demonstrated tremendous awareness of socio-economic, cultural and political issues, and who developed 
Leadership as sustainability

mechanisms to successfully work-around and/or within these parameters for the overall good of their schools (Oakes, et al, 2000), and for good of those who work and study therein. Leading change

We see evidence of school principals trying to move parents from simply being "involved" to being "engaged". This is an important juxtaposition and an important duty. Schools are about change, and schools cannot effectively lead change for students without significant input from parents. Using the school grounds as a teaching tool and resource, as well as providing students extra or co-curricular enrichment activities is also significant. Together, these symbolise an important stance being taken by school leaders, in trying to the shift mindsets and attitudes of staff and students in respect of how learning and teaching activities should or can be organised, and also in equipping and preparing students for life beyond their school and community contexts. Context shapes leaders, but leadership shapes context. School leaders in this study demonstrated consistency in their moral purpose towards change for students. They highlighted that, although schools were located in poor or volatile communities, were under or poorly resourced, and did not have excellent support from parents, they (the schools) were oases of knowledge and a force for social good. As a result, they were not content that their students or their schools should conform to stereotypes derived from the reality of living in these communities. We therefore, see evidence of principals putting activist thinking into action (Oakes et al, 2000).

\section{Leadership as sustainability}

Sustainable leaders have several qualities that are not different from other leaders. What sets them apart, however, is leadership that connects institutional context to wider contexts and trends, and leadership that is concerned about 'futures' and not just the 'now'. According to Strandberg (2015), “They understand the layers and complexities of relationships in the system 
Leadership as sustainability

within their business is located" (p.6). Furthermore, they engage in partnership working and collaboration that helps to build-up and uplift their organisations. This was a major strength among school leaders in the study who networked and collaborated with parent associations, community organisations, the education ministry and local businesses to provide skills, expertise and other resources that could help their schools achieve their goals. This is not only showing vision and foresight, but also tactical and practical skills in leadership underpinned by a sense of social justice which is reinforced by their desire to change the lives of students by providing them a "qualitatively different learning experience" (Miller 2016, p. 106).

School leaders invested in CPD for staff, provided concerted opportunities for students to engage in enrichment activities and devised different ways of working with parents. There was also a commitment to continue to contemplate ways of getting parents to more effectively engage. A result of the relative lack of parental engagement (not involvement) thus, led school leaders to re-design processes and to pursue new and innovative ways of working with students for the overall good of each student and the four the schools involved. We argue, these are not only characteristics of sustainable leadership but themselves constitute sustainable leadership. Furthermore, as we provided earlier, "sustainable leadership is not one single thing. Rather, it is a combination of a series of planned actions aimed at developing and/or multiplying the likely social, economic and environmental benefits from resources available today for use in the future”. This approach to leadership, thus, underlines Miller's (2012) suggestion that effective school leadership (and here we argue leadership that is sustainable) is practical, synergistic and holistic, drawing from and upon multiple sources as needs must.

\section{Conclusions}

School leadership is fraught, and doing sustainable school leadership is a fraught exercise. In a national educational context affected by poverty and economic problems, we see 
Leadership as sustainability

school leaders demonstrating vision and environmental awareness and political sophistication (Clarke \& Wildy, 2016). Poverty was not barrier high or strong enough to prevent school leaders from attempting to provide students with the best possible schooling experience. In fact, although being challenged by events and issues within their school, community and national economic contexts, school leaders actively, deliberately and purposefully challenged these events and issues. From his research on High Performing Principals in Jamaica, Hutton (2011) suggested that the process of engaging and successfully navigating environmental factors sharpens and intensifies the quality of leadership provided by school principals. Based on the evidence provided, we conclude that Jamaican primary school leaders have a difficult job in leading their schools, compounded by social, economic, resourcing, locational, staffing and other problems. We also conclude, however, that, in the face of economic, community, school challenges, Jamaican school leaders are defying the odds, thus, building and harnessing their own leadership, sharing leadership through collaborative partnerships with teachers and others, planning for succession, growing leadership through the provision of meaningful opportunities and targeted CPD, and providing students with deep and meaningful learning experiences, all of which are elements of sustainable leadership.

\section{Limitations and implications}

Not very much research has been conducted in Jamaica on leadership in primary schools. And not much research has been conducted on leadership in small primary schools and located in rural/ remote districts. A national study, that combines qualitative and quantitative methods of leadership in primary schools, led by researchers in the Institute for Educational Administration \& Leadership- Jamaica (IEAL-J) or the National College for Educational Leadership (NCEL) could prove insightful and helpful in understanding the 
Leadership as sustainability

practice of schools/ leaders, but also in enabling NCEL to more effectively build its training programme for aspiring principals on extensive local research evidence. Similarly, empowerment and capacity development programmes led by the IEAL-J could also benefit from this evidence base. Furthermore, such a national study could provide perspectival and pedagogical insights into how male and female school leaders, as well as how school leaders in geographic regions approach the practice school leadership. In addition, as this study of four school leaders did not consider teachers' views of sustainable leadership, a larger comparative study of how teachers and school leaders understand and enact sustainable leadership could provide an integrated assessment of sustainable school leadership among key actors in school leadership and improvement. 
Leadership as sustainability

\section{References}

Acker-Hocevar, M., Hyle, A., Ivory, G., \& McClellan, R. (2015). In, G. Ivory, A. Hyle, R. McClellan, \& M. Acker-Hocevar (Eds.), Quandaries of the small-district superintendency (pp. 1-14), New York: Palgrave Macmillan.

Baker, M., \& Foote, M. (2006). Changing spaces: Urban school interrelationships and the impact of standards-based reform, Educational Administration Quarterly, 42(1), 90123.

Bush, T. (2011). Succession planning and leadership development for school principals: comparing English and South African approaches, Compare: A Journal of Comparative and International Education, 41 (6), 785- 800.

Capra, F. (1997). The web of life: A new synthesis of mind and matter. London: HarperCollins.

Clarke, S., \& Wildy, H. (2016). Developing successful and effective leadership: Australian and Pacific perspectives. In. P. Pashiardis, \& O. Johansson (Eds), Successful school leadership: International perspectives, London: Bloomsbury.

Eacott, S. (2011). Preparing 'educational' leaders in managerialist times: An Australian story, Journal of Educational Administration and History, 43(1), 43-59.

Elkington J. (1997). Cannibals with Forks: The triple bottom line of 21 st Century Business, Oxford: Capstone Publishing

Foucault, M. (1981). The history of sexuality. Vol 1. Harmondsworth, Penguin.

Fullan, M. (2005). Leadership \& sustainability: System thinkers in action, Thousand Oaks, AC: Corwin Press. 
Leadership as sustainability

Glickman, C. D. (2002). Leadership for learning: How to help teachers succeed. Alexandria, VA: ASCD.

Gunter, H. M. (2005). Conceptualising research in educational leadership, Educational Management Administration \& Leadership, 33(2), 43-59.

Hargreaves, A., \& Fink, D. (2003). The seven principles of sustainable leadership, OISE Toronto: International Centre for Educational Change.

Hargreaves, A., \& Fink, D. (2004). The seven principles of sustainable leadership, Educational Leadership, 61(7), 8-13.

Harris, A., \& Spillane, J. (2008). Distributed leadership through the looking glass, Management in Education, 22(31), 31-4.

Hill, R., \& Matthews, P. (2010). Schools leading schools II: The growing impact of national leaders of education. Nottingham: National College for Leadership of Schools and Children's Services.

Hutton, D. (2011). Revealing the essential characteristics, qualities and behaviors of the high performing principal: experiences of the Jamaican school system, International Journal of Educational Leadership Preparation, 5(3), 1-15.

Hutton, D.M., \& Johnson, B. (2017). Leadership for success: The Jamaican school experience, Kingston, Jamaica: University of the West Indies Press.

Miller, P. (2012). The changing nature of educational leadership: 'educational leadership in the Caribbean \& beyond' (editorial), Journal of the University College of the Cayman Islands, Special Issue, JUCCI 6. 
Leadership as sustainability

Miller, P. (2013a). The politics of progression: Primary teachers' perceived barriers to gaining a principalship in Jamaica, Kingston: University of Technology, Jamaica \& the Institute for Educational Administration \& Leadership - Jamaica.

Miller, P. (Ed.) (2013b). School leadership in the Caribbean: Perceptions, practices, paradigms, London: Symposium Books.

Miller, P. (2016). Exploring school leadership in England and the Caribbean: New insights from a comparative approach, London: Bloomsbury.

Miller, P. (2018). The nature of school leadership: Global practice perspectives, London: Palgrave McMillan.

Ministry of Education (2016). Education Statistics 2015-2016: Annual statistical review of the education sector, Kingston, Jamaica: Planning and Development Division, MoE.

Oakes, J., Quartz, K. H., \& Lipton, M. (2000). Becoming good American schools: The struggle for civic virtue in education reform. San Francisco: Jossey-Bass.

Pont, B., Nusche, D., \& Moorman, H. (2008) Improving School Leadership: Volume 1: Policy and Practice, Paris: OECD

Scott, W. (2013). Developing the sustainable school: Thinking the issues through. Retrieved from:

http://www.bath.ac.uk/cree/resources/DEVELOPING_THE_SUSTAINABLE_SCHO $\underline{\text { OL.pdf }}$

Spillane, J. P., Halverson, R., \& Drummond, J. B. (2001). Investigating school leadership practice: A distributed perspective. Educational Researcher, 30(3), 23 - 28.

Stoll, L., Fink, D., \& Earl, L. (2002). It's about learning (and it's about time). London: Routledge/Falmer. 
Leadership as sustainability

Strandberg, C. (2015). Sustainability competencies and talent management: The new business imperative. Retrieved from: http://corostrandberg.com/wpcontent/uploads/2015/02/sustainability-competencies-feb-17-final-draft.pdf.

Task Force on Educational Reform (2005). A Transformed Education System Report revised edition, Kingston: Jamaica Information Service.

Ulrick, A., \& Bowers, A. (2014). What Are the Different Types of Principals Across the United States? A Latent Class Analysis of Principal Perception of Leadership, Educational Administration Quarterly, 50 (1), 96-134.

United Nations (1987). Our common future: The World Commission on Environment and Development, Oxford: Oxford University Press. 